\title{
Evaluation of Land Suitability for Cocoa Plants: A Case Study in Aranio District, Banjar District, South Kalimantan
}

\author{
Aminatullaila ${ }^{1}$ Sidharta Adyatma ${ }^{1}$ Deasy Arisanty ${ }^{1}$ Parida Angriani ${ }^{*}$ \\ ${ }^{I}$ Department of Geography Education, Lambung Mangkurat University, Banjarmasin, Indonesia \\ ${ }^{*}$ Corresponding author. Email: parida.angriani@ulm.ac.id
}

\begin{abstract}
Land can be said to be suitable for the development of a certain agricultural commodity, if it is included in the appropriate category both biophysically and socio-economically. This study aims to determine the land suitability class for cocoa plant commodities in Aranio District. The research methods used were survey methods and matching methods. The map used is a map of land units obtained from overlaying several maps, namely land form maps, land use maps, slope maps, and soil maps. The study population consisted of 12 land units, namely 11 denudational landforms and 1 fluvial landform. The sample was determined using a random sampling technique with a total of 2 samples for each land unit. Primary data comes from field observations and laboratory tests, while secondary data comes from literature studies. The data were analyzed by matching the growth requirements of the cocoa plant with the land suitability map. The results showed that the evaluation of land suitability for cocoa plant commodities in Aranio District has 3 classes, namely class S3 (according to marginal), N1 (currently unsuitable), and S2 (appropriate), with limiting factors: slope, soil pH, P2O5, erosion hazard, effective depth, and surface rock.
\end{abstract}

Keywords: Evaluation of land suitability, cocoa plants, matching

\section{INTRODUCTION}

Land evaluation is the process of estimating land potential for various alternative land uses $[1,2]$. The use of land that is not in accordance with its capabilities, in addition to causing damage, will also increase poverty and other social problems [3]. Land suitability is a description of the level of land suitability contained in a plot of land for certain land uses. The land suitability class can be different, it really depends on the type of land use to be evaluated $[4,5]$.

Cocoa (Theobroma Cacao L) is a commodity originating from tropical regions of South America, and one of the agricultural crops that has an important and reliable role in realizing agricultural development programs, especially as a source of income, employment, and foreign exchange. Cocoa is the 3rd largest foreign exchange producing commodity in the plantation sector after rubber and oil palm $[6,7]$.

Cocoa is a new plantation commodity that will be cultivated in Banjar Regency. Cocoa is planned to be the third leading commodity after rubber and oil palm. According to the Head of the Department of Animal Husbandry and Plantation Banjar, cocoa development has started since the end of 2018 (BanjarmasinPost, 2019). Plantation yields in Banjar Regency always experience a high enough increase every year and many types of plantation crops have been developed except for cacao.

Aranio Subdistrict is the largest sub-district in Banjar Regency, which is around 1,166.35 hectares, and there are about 8,820 dry lands that are still untapped. The untapped dry land has great potential for cocoa cultivation which allows residents in Aranio District to increase agricultural production not only in rubber and oil palm [8]. Land suitability for cocoa plants can be determined through evaluation of land suitability, so that land can be used appropriately and sustainably, in addition to avoiding the risk of decreasing land productivity due to inappropriate use [9]. The purpose of this research is to determine the level of land suitability for cocoa plants in Aranio District, Banjar Regency, South Kalimantan.

\section{STUDY THEORY}

Land suitability evaluation or often called land evaluation, is part of the land use planning process and one of its activities is land suitability classification. In principle, land suitability classification compares between the requirements for the type of land use to be applied and the properties or quality of land owned by the land to be used $[1,2]$. Land suitability evaluation is a description of the suitability of a plot of land for a particular use. The actual land suitability is the suitability of land based on the data on the biophysical properties of the soil or land resources before the input is given necessary to overcome the constraints. The biophysical data is in the form of soil and climatic characteristics related to the growing requirements of the evaluated plants. Potential land suitability describes the suitability of land that will be achieved if improvement efforts are made [10]. 
When viewed based on the requirements for growing cocoa plants in the Land Suitability Evaluation and Land Use Planning book [11] regarding the requirements for growing plants, the requirements for growing this plant are as follows:

Table 1 Requirements for Growing Cocoa Plants

\begin{tabular}{|c|c|c|c|c|c|c|}
\hline \multirow{2}{*}{ No } & \multirow{2}{*}{ Characteristics } & \multicolumn{5}{|c|}{ Land Suitability Class } \\
\hline & & S1 & S2 & S3 & N1 & N2 \\
\hline \multirow{2}{*}{1} & \multicolumn{6}{|c|}{ Temperature (t) } \\
\hline & Annual average $\left({ }^{\circ} \mathrm{C}\right)$ & $25-28$ & $>28-32$ and $20-<25$ & $>32-35$ & $\mathrm{Td}$ & $>32-<20$ \\
\hline \multirow{3}{*}{2} & \multicolumn{6}{|c|}{ Water Availability (w) } \\
\hline & Dry Month $(>75 \mathrm{~mm})$ & $>1-2$ & $>2-3$ & $>3-4$ & $\mathrm{Td}$ & $>4$ \\
\hline & Rainfall / annual (mm) & $1500-2500$ & $>2500-3000$ & $3000-4000,1250-<1500$ & - & $>4000$ and $<1250$ \\
\hline \multirow{4}{*}{3} & \multicolumn{6}{|c|}{ Root Media (r) } \\
\hline & Soil Drainage & Good & Moderate & Somewhat Obstructed & Stuck, rather fast & $\begin{array}{l}\text { Very hampered, } \\
\text { fast }\end{array}$ \\
\hline & Texture & $\begin{array}{l}\text { SL, L, SCL, SiL, } \\
\text { Si, CL, SiCL }\end{array}$ & LS, SC, SiC, C & Str, C & - & Gravel, sand \\
\hline & Effective Depth $(\mathrm{cm})$ & $>100$ & $75-100$ & $50-<75$ & - & $<50$ \\
\hline \multirow{4}{*}{4} & \multicolumn{6}{|c|}{ Nutrient retention (f) } \\
\hline & KTK Land & High & Moderate & low & - & Very low \\
\hline & Soil pH & $5.5-6.5$ & $>6.5,5.0-<5.5$ & $<7.5-8.5,4.5-<5.0$ & $4.0-<4.5$ & $>8.5<4.0$ \\
\hline & Base saturation & $>35$ & $20-35$ & $<20$ & - & - \\
\hline \multirow{2}{*}{5} & \multicolumn{6}{|c|}{ Toxicity (x) } \\
\hline & Salinity (mmhos / cm) & $<1$ & $>1-3$ & $>3-4$ & $>4-6$ & $>6$ \\
\hline \multirow{4}{*}{6} & \multicolumn{6}{|c|}{ Available Nutrient (n) } \\
\hline & Total $\mathrm{N}$ & Moderate & Low & Very low & - & - \\
\hline & $\mathrm{P} 2 \mathrm{O} 5$ & Moderate & Low & Very low & - & - \\
\hline & $\mathrm{K} 2 \mathrm{O}$ & $\geq$ Moderate & Low & Very low & - & - \\
\hline \multirow{3}{*}{7} & \multicolumn{6}{|c|}{ Land Preparation (p) } \\
\hline & Surface Rocks (\%) & $<3$ & $>3-15$ & $>15-40$ & $\mathrm{Td}$ & $>40$ \\
\hline & Rock outcrop (\%) & $<2$ & $>2-10$ & $>10-25$ & $>25-40$ & $>40$ \\
\hline \multirow{3}{*}{8} & \multicolumn{6}{|c|}{ Erosion Hazard } \\
\hline & Erosion hazard & SR & $\mathrm{R}$ & $\mathrm{S}$ & $\mathrm{B}$ & SB \\
\hline & Slope (\%) & $<8$ & $>8-15$ & $>15-25$ & $>25-45$ & $>45$ \\
\hline 9 & Flood Hazard & F0 & $\mathrm{F} 1$ & F2 & F3 & $\mathrm{F} 4$ \\
\hline
\end{tabular}

Source: Widiatmaka, 2007).

Information:

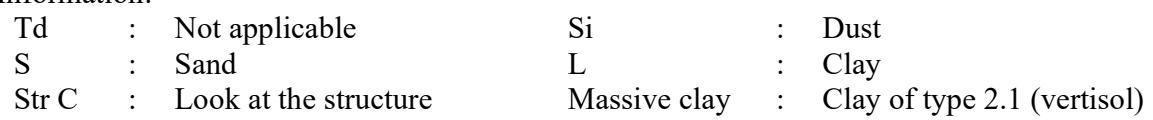

\section{RESEARCH METHOD}

The research was conducted in Aranio District, Banjar Regency, South Kalimantan. Astronomically this district is located at 309'34 "-3017'58" South Latitude and 1150 7'50 "-11505'13" East Longitude. The research methods used in this study are survey methods and matching methods. The sample map uses a land unit map obtained from the overlapping map of land forms, land maps, land use maps, and slope maps with a map scale of 1:100,000. The survey method was used to measure and take samples in the field, while the matching method was used to match the characteristics of the land in each study area with the growing requirements for cocoa crops, in order to obtain appropriate directions for cocoa land use in Aranio District. The study population consisted of 12 land units, namely 11 
denudational landforms and 1 fluvial landform. The sample was determined using a random sampling technique with a total of 2 samples for each land unit.

\section{RESULTS AND DISCUSSION}

Land suitability is the level of equality on a plot of land used for certain uses [12]. Land suitability is assessed at its current condition (present) or after improvements have been made [13]. The current land suitability is known as the actual land suitability, while the potential land suitability, namely the new land will get improvement [10]. Evaluation of a land will be easier to do if the land unit is defined by the criteria for land characteristics used in the land evaluation $[13,14]$. The characteristics of the land studied to determine the suitability of land for cocoa plants are water availability, temperature, nutrient rhythm, root media, toxicity, land preparation, available nutrients, erosion hazard levels, flood hazards $[10,15]$.

The average annual temperature in the study area is $27^{\circ} \mathrm{C}$. The most suitable temperature for cocoa is $25-28^{\circ} \mathrm{C}$. The average annual rainfall in the study area from data obtained from 2009-2018 is around 2,053.144 mm / year, and the most suitable rainfall (S1) based on the growing requirements for cocoa is $1500-2500 \mathrm{~mm} /$ year. The wet months and dry months in Aranio District based on the schmidt-ferguson climate classification are 96 dry months and 24 wet months. Soil textures in the research area are clayey loam, sandy loam, sandy loam, loamy, and sandy loam. The effective depth from the measurement results in the field is $20->120 \mathrm{~cm}$.

According to the results of the ULM Agriculture and Animal Husbandry Laboratory, Cation Exchange Capacity (CEC) and base saturation reached 18-29 and base saturation reached $11-72 \%$. Soil acidity $(\mathrm{pH})$ obtained from the field results in each land unit, namely 4-5.5. Soil toxicity is a poison in the soil that causes a reduction in soil quality for the growth of a plant. The main toxicity is salinity. Salinity is the amount of salt content in the soil. The salinity in Aranio District is 1.21. Available nutrients that affect the quality of a land consist of phosphate $\left(\mathrm{P}_{2} \mathrm{O} 5\right)$, nitrogen $(\mathrm{N}-$ t0tal), phosphate $\left(\mathrm{P}_{2} \mathrm{O} 5\right)$, and potassium content $(\mathrm{K} 2 \mathrm{O})$. According to the results of the Soil Laboratory of the Faculty of Animal Husbandry and Agriculture, the total Ncontent is $0.9-0.24$, the phosphate content is 2.22-73,

The ground condition in the field is expressed as a percentage, namely surface rock and exposed rock. The surface rock in the field from the results of the field in each land unit is that the average rock has $0-<15 \%$, the exposed rocks in the research area from the observation results are $0-4 \%$. The slope is based on the results of field engraving using abney level, which has a $2-70 \%$ slope. The erosion hazards that exist in the research area are based on field observations, namely mild and very light. The level of flood hazard in the research area is based on field observations and interviews with the surrounding community, namely the absence of a flood hazard (F0), mild (F1), and rather severe (F3).

Land suitability is the level of similarity to a plot of land used as land use. Land evaluation is an approach used as an assessment of potential land resources[7,16]. Evaluation of land suitability was analyzed using a matching method with plant growth requirements in the land suitability class criteria and land characteristics in each land unit at the research location using a table of land suitability criteria including the requirements for certain plant conditions to be evaluated [9]. The results of the land evaluation provide information or direction for the required land use, and the expected production values can be obtained $[18,19,20]$.

The land suitability classes obtained based on the matching results with the growing conditions for kaka0 plants in Aranio District are presented in Table 2.

Table 2 Land Suitability Class in Aranio District, Banjar Regency

\begin{tabular}{|c|c|c|c|c|}
\hline No & Unit of Land & Coordinate point & Class & Factor Limiter \\
\hline 1 & IN I Lt LD & $03^{\circ} 30^{\prime} 51$ "LS - $114^{\circ} 599^{\prime} 40^{\prime \prime}$ East Longitude & N1 & Slope \\
\hline 2 & IN I La LD & $03^{\circ} 29^{\prime} 11.17$ "LS - $114^{\circ} 50 ' 29.74 "$ East Longitude & S2 & $\begin{array}{l}\text { Soil } \mathrm{pH} \text {, total N, P2O5, erosion } \\
\text { hazard, slope, flood hazard }\end{array}$ \\
\hline 3 & DII I Li H & $03^{\circ} 26^{\prime} 02^{\prime \prime L S}-115^{\circ} 10^{\prime} 03^{\prime}$ East Longitude & S2 & $\begin{array}{l}\text { Effective depth, soil } \mathrm{pH} \text {, Total } \mathrm{N} \text {, } \\
\text { slope, erosion }\end{array}$ \\
\hline 4 & DIII III Li H & - & - & - \\
\hline 5 & DV I La SB & $03^{\circ} 31^{\prime} 06^{\prime \prime L S}-115^{\circ} 06^{\prime} 59^{\prime \prime}$ East Longitude & N1 & P2O5, Effective depth, soil $\mathrm{pH}$ \\
\hline 6 & DVI III Lt LD & $03^{\circ} 29^{\prime} 36^{\prime \prime}$ LS - $114^{\circ} 59^{\prime} 29^{\prime \prime}$ East Longitude & N1 & $\mathrm{P} 2 \mathrm{O} 5$ \\
\hline 7 & DVI III Al W & - & - & - \\
\hline 8 & DVII III La H & $03^{\circ} 37^{\prime} 13^{\prime \prime}$ LS - $115^{\circ} 02^{\prime} 10^{\prime \prime}$ East Longitude & S3 & Surface Rocks \\
\hline 9 & DVIII I La LD & $03^{\circ} 26^{\prime} 35^{\prime \prime L S}-115^{\circ} 8^{\prime} 14^{\prime \prime}$ East Longitude & N1 & Soil pH \\
\hline 10 & DIX I La H & $03^{\circ} 32^{\prime} 38.3^{\prime \prime L S}-115^{\circ} 13^{\prime} 15.9^{\prime \prime}$ East Longitude & N1 & $\mathrm{P} 2 \mathrm{O} 5$ \\
\hline 11 & DXI II La H & $03^{\circ} 36^{\prime} 33^{\prime \prime L S}-115^{\circ} 02^{\prime} 40^{\prime \prime}$ East Longitude & S3 & $\mathrm{P} 2 \mathrm{O} 5$ \\
\hline 12 & FI I La KC & $03^{\circ} 30^{\prime} 22$ "LS - $115^{\circ} 4 ' 29 "$ East Longitude & N1 & $\mathrm{P} 2 \mathrm{O} 5$ \\
\hline
\end{tabular}

Source: Field Analysis, 2019 
The land suitability class level for cocoa commodity in Aranio District based on the table above for land unit 1 has suitability class N1 (temporary not suitable) having a slope limiting factor. Land unit 2 is included in the appropriate class (S2) limiting factors, namely slope, soil $\mathrm{pH}$, total $\mathrm{N}$, $\mathrm{P} 2 \mathrm{O}$, erosion hazard, slope, flood hazard land unit 3 is included in the suitability class category S2 (appropriate) has an effective depth limiting factor, soil $\mathrm{pH}$, total $\mathrm{N}$, slope and erosion, land unit 5 belonging to class N1 (not suitable temporarily) has a limiting factor $\mathrm{P} 2 \mathrm{O} 5$, effective depth, and soil $\mathrm{pH}$. Land unit 6 is included in class $\mathrm{N} 1$ (temporarily unsuitable) has a limiting factor P2O5, land unit 8 has a moderately suitable suitability class (S3) with a limiting factor for surface rock. Land units belonging to class N1 (temporarily unsuitable) have a limiting factor for soil $\mathrm{pH}$. Land unit 10 has a temporary unsuitable suitability class (N1) with a limiting factor P2O5. Land unit 11 has a fairly suitable or marginal suitability class (S3) and has a limiting factor P2O5. The 12 land units belonging to class N1 (not suitable at this time) have a limiting factor P2O5.

Slope limiting factors can result in the root being not strong enough to bind the soil as a foundation so that it makes plants fall and break easily. The limiting factor for surface rock can make it difficult to cultivate the soil to become a place to plant crops. Soil $\mathrm{pH}$ limiting factors that are more or less acidic and alkaline can make it difficult for plants to grow and develop. The lack of P2O5 content is very influential for plants, because the content of phosphate plays an important role in the process of synthesis, energy transfer and storage and other plant metabolic processes. The map of the results of land suitability classes in Aranio District is as follows:

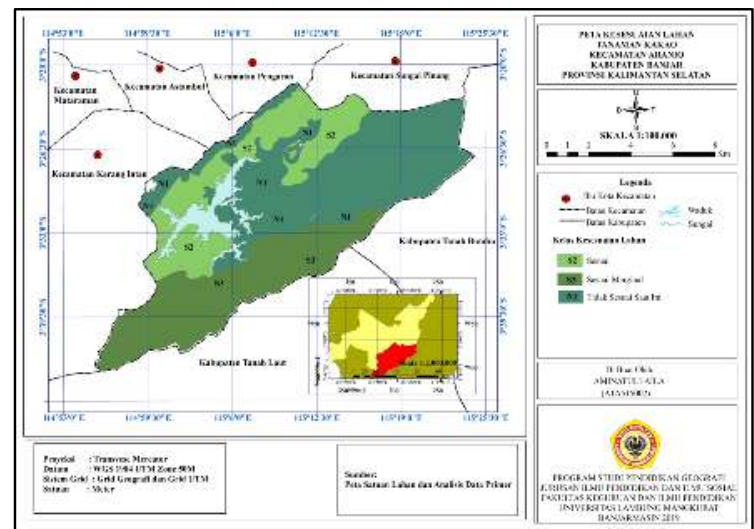

Figure 1 Land Suitability Map in Aranio District

\section{CONCLUSION}

Land suitability class for cocoa commodity development in Arani0 District, Banjar Regency, South Kalimantan is in the Appropriate class (S2), which is in Bunglai Village and Rantau Balai Village with slope limiting factors, soil $\mathrm{pH}$, effective depth, P2O5, total N, erosion hazard, slopes, flood hazard; Sufficiently Suitable or Suitable for Marginal (S3) is found in Belangian Village with limiting factors for surface rock and $\mathrm{P} 2 \mathrm{O}$, and permanent non-conformity
(N1) is found in Artain Village, Aranio Village, Rantau Bujur, and Tiwingan Baru Village with the limiting factor $\mathrm{P} 2 \mathrm{O} 5$, soil $\mathrm{pH}$, and the effective depth of soil. Slope limiting factors can result in the root being not strong enough to bind the soil as a foundation so that it makes plants fall and break easily. The limiting factor for surface rock can make it difficult to cultivate the soil to become a place to plant crops. Soil $\mathrm{pH}$ limiting factors that are more or less acidic and alkaline can make it difficult for plants to grow and develop. The lack of P2O5 content is very influential for plants, because the content of phosphate is very important in the process of photosynthesis, energy transfer and storage and other plant metabolic processes.

\section{REFERENCES}

[1] H. P. Sofianto, "Evaluasi Kesesuaian Lahan untuk Tanaman Kakao (Theobroma Cacao L.) Di Kenagarian Sitiung Kecamatan Sitiung Kabupaten Dharmasraya," Padang: Universitas Andalas, 2019.

[2] dan S. P. Sukarman, Anny Mulyani, "Modifikasi Metode Evaluasi Kesesuaian Lahan Berorientasi Perubahan Iklim," J. Sumberd. Lahan, vol. 12, no. 1, pp. 1-11, 2018.

[3] M. Mubekti, "Evaluasi Karakterisasi Dan Kesesuaian Lahan Untuk Komoditas Unggulan Perkebunan : Studi Kasus Kabupaten Kampar," J. Teknol. Lingkung., vol. 13, no. 1, p. 37, 2012.

[4] D. M. Arkha Dhemas Gunanda, "Evaluasi Kesesuaian Lahan Tanaman Perkebunan Sebagai Faktor Pengurang Dampak Erosi di DAS Bendo, Banyuwangi, Jawa Timur," Bumi Indones., vol. 4, no. 4, 2015.

[5] S. Ritung, Petunjuk Teknis Evaluasi Lahan untuk Komoditas Pertanian. Bogor: Balai Besar Penelitian dan Pengembangan Sumberdaya Lahan Pertanian, 2011.

[6] Y. A. Mizar Liyanda, Abubakar Karim, "Analisis Kriteria Kesesuaian Lahan Terhadap Produksi Kakao Pada Tiga Klaster Pengembangan di Kabupaten Pidie," J. Agrista, vol. 16, no. 2, pp. 62-79, 2012

[7] M. N. La Ode Safuan, Aminuddin Mane Kandari, "Evaluasi Kesesuaian Lahan Tanaman Kakao (Theobroma cacaoL.) Berdasarkan Analisis Data Iklim Menggunakan Aplikasi Sistem Informasi Geograf," J. Agroteknos, vol. 3, no. 2, pp. 80-85, 2013.

[8] BPS Kabupaten Banjar 2018, "Kecamatan Aranio Dalam Angka," Kabupaten Banjar, 2018.

[9] M. Tufaila, Aliyaman, S. Ginting, and S. ALAM, "Evaluasi Kesesuaianlahan Untuktanaman Kopi, Kakao, Dan Jambu Mete Dikecamatan Moramo Utara Kabupaten Konawe Selatan," $J$. Agroteknos, vol. 4, no. 3, pp. 167-173, 2014.

[10] S. Ritung, Panduan Evaluasi Kesesuaian Lahan. Bogor: World Agroforestry Centre, 2007. 
[11] S. Widiatmaka, Evaluasi Lahan dan Perencanaan Tata Guna Lahan. Yogyakarta: Universitas Gadjah Mada, 2007.

[12] Y. Maglinets, K. Raevich, and G. Tsibulsky, "The Intelligent Managerial Decision Support System for Agricultural Land Evaluation," $E 3 S \mathrm{Web}$ Conf., vol. 75, pp. 1-5, 2019.

[13] M. A. E. AbdelRahman, A. Shalaby, and E. F. Essa, "Quantitative land evaluation based on fuzzy-multi-criteria spatial model for sustainable land-use planning," Model. Earth Syst. Environ., vol. 4, no. 4, pp. 1341-1353, 2018.

[14] Fao, A Fremework For Land Evaluation. Wageningen, 1997.

[15] U. P. Jawang, B. H. Simanjuntak, and T. M. P. Prihtanti, "Land Suitability Evaluation of Commodities Pre-eminent Plantations in South Katiku Tana District Central Sumba Regency," J. Pengelolaan Sumberd. Alam dan Lingkung. (Journal Nat. Resour. Environ. Manag., vol. 8, no. 3, pp. 396-405, 2018.
[16] T. Nofelman, A. Karim, and A. Anhar, "Analisis Kesesuain Lahan di Kabupaten Simeulue," Manaj. Sumberd. Lahan, vol. 1, no. 1, pp. 62-71, 2012.

[17] U. Supraptiningsih, "Karakteristik Pengemis Perempuan Di Kecamatan Tlanakan Kabupaten Pamekasan," NUANSA J. Penelit. Ilmu Sos. dan Keagamaan Islam, vol. 13, no. 2, p. 357, 2016, doi: 10.19105/nuansa.v13i2.1104.

[18] Pryo Adi Nugroho dan Istianto, "Penilaian Beberapa Sistem Evaluasi Lahan yang Telah Eksisting Untuk Tanaman Karet," J. Penelit. Karet, vol. 31, no. 2, pp. 88-101, 2013.

[19] J. R. Landon, Booker Tropical Soil Manual: A Handbook for Soil Survey and Agricultural Land Evaluation in the Tropics And Subtropics. New York: Routledge, 2014.

[20] M. El Sayed Said et al., "On the use of multivariate analysis and land evaluation for potential agricultural development of the northwestern coast of Egypt," Agronomy, vol. 10, no. 9, 2020, doi: 10.3390/agronomy 10091318 . 